\title{
Kadar Pigmen Total, Antosianin dan Angka Lempeng Total Ikan Cakalang (Katsuwonus Pelamis L) Asap yang Direndam Larutan Kulit Buah Manggis (Garcinia Mangostana L)
}

\author{
Fauzan Alfianto $^{1}$, Hens Onibala ${ }^{1}$ dan Feny Mentang ${ }^{1}$, Agnes T. Agustin ${ }^{1}$, \\ Grace Sanger $^{1}$, Daisy M. Makapedua ${ }^{1}$, Verly Dotulong ${ }^{1}$. \\ 1Program Studi Teknologi Hasil Perikanan \\ Fakultas Perikanan dan Ilmu Kelautan, Universitas Sam Ratulangi. \\ Jl. Kampus Unsrat Bahu, Manado 95115, Sulawesi Utara, Indonesia. \\ *Penulis Korespondensi: fauzan.alfianto.fa@gmail.com \\ (Diterima 15-01-2020; Direvisi 22-05-2020; Dipublikasi XX-05-2020)
}

\begin{abstract}
ABSTRAK
Tujuan penelitian ini. Untuk mendapatkan ekstrak kulit buah manggis yang dikeringkan selama 4 dan 8 hari sebagai bahan pengawet. Metode yang digunakan untuk analisa antosianin adalah Lee, et al., (2005), analisa pigmen total menggunakan metode Briton, et al., (1995) dan analisa angka lempeng total menggunakan metode Fardiaz (1993). Hasil yang diperoleh dari ikan cakalang asap yang direndam dalam larutan kulit buah manggis memiliki nilai angka lempeng total (ALT) tertinggi terdapat pada hari ke 10 waktu pengeringan 8 hari lama perendaman 15 menit dengan nilai 1,50 koloni/gram. Sedang kan Nilai terendah 0 hari dengan waktu pengeringan 4 hari lama perendaman 30 menit dengan nilai 2,6 koloni/gram. Data hasil pigmen total kandungan tertinggi terdapat pada pengeringan hari ke 4 dengan nilai $68,67 \mu \mathrm{g} / \mathrm{g}$. sedangkan nilai terendah pengeringan 8 hari dengan nilai $19,95 \mu \mathrm{g} / \mathrm{g}$. Data hasil Antosianin waktu pengeringan 4 hari memperoleh kadar $191,11 \mathrm{mg} / \mathrm{L}$ sedangkan antosianin waktu pengeringan 8 dengan kadar $62,37 \mathrm{mg} / \mathrm{L}$.
\end{abstract}

Kata kunci: Manggis, Total Plate Count, Pigmen Total, Antosianin.

\section{PENDAHULUAN}

Ikan merupakan salah satu hasil perikanan yang memiliki kandungan gizi yang tinggi. Cara pengolahan ikan pun berbeda-beda sesuai permintaan, dan salah satunya diolah melalui pengasapan menjadi ikan asap atau dikenal ikan fufu yang menjadi istilah bagi masyarakat Sulawesi Utara.

Ikan asap merupakan salah satu produk olahan tradisional hasil perikanan yang sangat disukai oleh masyarakat Indonesia. Berbagai jenis ikan dapat diolah menjadi ikan asap seperti ikan manyung (Arius thallasinus), tongkol (Auxis thazard), pari (Dasyatis bleekeri), ikan bandeng (Chanos chanos Forsk), cakalang (Katsuwonus pelamis), dan tuna (Thunus albacares) (Swastawati et al, 2013a; Swastawati, 2008).

Undang-undang Nomor 7 Tahun 1996 tentang Pangan dan Undang- undang Nomor 31 Tahun 2004 tentang Perikanan, serta Peraturan Pemerintah Nomor 28 Tahun 2004 tentang keamanan mutu dan gizi pangan telah ditetapkan agar produk pangan dalam hal ini hasil perikanan yang dipasarkan untuk konsumsi manusia harus mengikuti persyaratan-persyaratan yang ditetapkan sehingga dapat menjamin kesehatan manusia.

Indonesia sebagai salah satu produsen terbesar di dunia. Data dari Badan Pusat Statistik pada tahun 2017 produksi manggis di Indonesia mencapai 161,751 ton. Banyaknya produksi buah manggis akan menimbulkan masalah pada lingkungan terutama yang disebabkan oleh kulit buah manggis setelah isinya dikomsumsi. Menurut Tambunan (1998) dan Subroto (2008) kulit buah manggis mempunyai sifat sebagai anti-aging, menurunkan tekanan darah tinggi, menurunkan berat badan, antivirus juga antibakteri.

Kulit manggis memiliki aktivitas antioksidan, anti bakteri, anti inflamasi dan antialergi, serta aktivitas antikanker, diantaranya kanker hepatoseluler, kanker payudara dan leukemia. Xanton yang telah diisolasi dari kulit, buah, kulit kayu dan daun manggis dalam beberapa studi menunjukkan bahwa xanton yang terkandung tersebut memiliki aktivitas farmologi, antioksidan, antitumor, antiinflamasi, antialergi, antifungi dan antivirus adalah beberapa aktivitas farmakologi yang telah dilaporkan terdapat dalam xanton yang diisolasi dari manggis (Widia, 2013). 
Menurut $\mathrm{Yu}$ et al., (2007) kulit buah manggis mengandung senyawa-senyawa fenolik. Senyawa fenolik yang ada dalam jumlah besar di dalam kulit buah manggis adalah antosianin, xanthone, tannin, dan asam fenolat (Zadernowski et al., 2009). Selain senyawa tersebut, Yu et al., (2007) juga menyatakan bahwa kulit buah manggis mengandung turunan senyawa polifenol berupa protosianidin.

Tujuan penelitian ini adalah mendapatkan ekstrak kulit buah manggis yang dikeringkan selama 4 dan 8 hari sebagai bahan pengawet yang aman digunakan dalam pengolahan produk perikanan khususnya ikan asap. Hasil Penelitian ini diharapkan dapat memberikan informasi kepada masyarakat tentang mutu produk ikan asap menggunakan ekstrak kulit manggis terhadap mikrobiologi dan memberikan informasi berupa pentingnya limbah kulit buah manggis dalam dunia pangan.

\section{METODE PENELITIAN}

\section{Alat dan Bahan}

Alat yang digunakan antara lain: spektrofotometer UV-Vis 1800 Shimadzu, timbangan analitik, oven, Erlenmeyer, Magnetic stirrer, tabung reaksi, spatula, pipet/mikro steril, beaker glass, gelas ukur, cawan petri, autoclave, laminar flow, inkubator, wadah penyimpanan/piring, pisau, tissue, mortar, beker glass, gelas ukur, kain blachu dan drum pengasapan.

Bahan yang digunakan dalam penelitian ini antara lain Bahan baku utama yang dijadikan sampel untuk penelitian ini yaitu produk ikan cakalang (Katsuwonus pelamis L.) yang dibeli dari pasar bahu Manado dan buah manggis yang dibeli dari pasar Bersahati Manado. Bahan Kimia yang digunakan Nutrient Agar (NA), akuades dan ( $\mathrm{NaCl}$,), etanol $95 \%$.

\section{Persiapan Sampel}

\section{Pengambilan sampel ikan cakalang}

a. Ikan cakalang dibeli dari pasar Bahu Manado sebanyak 6 ekor yang berukuran $\pm 1 \mathrm{~kg}$. Agar ikan tetap terjaga mutunya ikan ditempatkan ke dalam cool box dan diberi es lalu dibawa ke laboratorium penanganan dan pengolahan hasil perikanan untuk diproses pengasapan.

b. Sebelum dilakukan pengasapan, ikan disiangi, dimana insang dan isi perut dibuang lalu dicuci dengan air bersih.

c. Kemudian ikan difilet terlebih dahulu sebelum dilakukan pengasapan.

\section{Pembuatan Larutan Kulit Buah Manggis}

a. Manggis sebelum dibuat ekstrak disortir terlebih dahulu, manggis yang masih terlihat segar diambil untuk dibuat larutan.

b. Setelah mendapatkan manggis yang baik langkah selanjutnya adalah pencucian buah manggis. Setelah buah manggis bersih dibelah satu demi satu dan kemudian pisahkan isinya.

c. Kulit manggis yang sudah dipisahkan dari isinya kemudian dipotong halus dengan menggunakan gunting.

d. Keringkan kulit buah manggis selama 4 dan 8 hari pada suhu ruang $\left(28-30^{\circ} \mathrm{C}\right)$.

e. Kulit manggis yang sudah kering kemudian dihaluskan dengan menggunakan blender dan dipisahkan untuk pengeringan 4 dan 8 hari. Kemudian kulit buah manggis yang sudah berbentuk bubuk di simpan dengan menggunakan kantong plastik.

\section{Perendaman Ikan Cakalang dengan larutan Kulit Buah Manggis.}

Kulit Manggis yang sudah berbentuk bubuk ditimbang sebanyak $50 \mathrm{~g}$ dari pengeringan 4 hari dan $50 \mathrm{~g}$ pengeringan 8 hari. $50 \mathrm{~g}$ diambil berdasarkan hasil penelitian Bentalen et al., (2017). kemudian siapkan ikan cakalang yang sudah difilet sebanyak 12 filet untuk direndam dengan larutan kulit buah manggis. Sebelum melakukan perendaman larutan kulit manggis dimasukan ke dalam air dan disaring dengan menggunakan kain saring. tiap $50 \mathrm{~g}$ bubuk manggis dilarutkan ke dalam air sebanyak $1000 \mathrm{ml}$. Perendaman ikan cakalang dilakukan dengan waktu yang berbeda yaitu 15 menit dan 30 menit. 


\section{Pengasapan Ikan}

Proses pengasapan ikan berlangsung selama $4-5$ jam dengan suhu pengasapan $70-80^{\circ} \mathrm{C}$ sesudah proses pengasapan, ikan didinginkan selama 30 menit untuk diuji lanjut. Parameter yang digunakan untuk uji lanjut adalah Uji TPC, dan Kadar Pigmen Total dengan konsentrasi larutan kulit buah manggis sebanyak 50 g pada pengeringan 4 hari dan 8 hari.

\section{Perlakuan dan Rancangan Percobaan}

Penelitian ini dirancang dengan menggunakan rancangan acak lengkap (RAL) yang disusun secara faktorial $2 \times 2 \times 3$ dan setiap perlakuan diberikan dua kali ulangan. Rancangan acak lengkap menurut Steel dan Torrie (1991).

Faktor $\mathrm{A}=$ Lama pengeringan kulit buah manggis

A1 $=$ Pengeringan 4 hari

A2 $=$ Pengeringan 8 hari

Faktor $\mathrm{B}=$ lama perendaman ikan cakalang dalam larutan kulit buah manggis.

$\mathrm{B} 1=15$ menit.

$\mathrm{B} 2=30$ menit.

Faktor $\mathrm{C}=$ Lama penyimpanan ikan cakalang asap dalam suhu ruang.

$\mathrm{C} 1=0$ hari.

$\mathrm{C} 2=5$ hari.

$\mathrm{C} 3=10$ hari.

\section{Analisis Angka Lempeng Total (Fardiaz, 1993 yang dimodifikasi)}

Angka lempeng total (ALT) atau perhitungan jumlah bakteri bertujuan untuk menentukan secara kuantitatif jumlah koloni bakteri yang tumbuh pada media agar. Prosedur perhitungan jumlah koloni bakteri sebagai berikut:

1. Semua peralatan yang digunakan dalam analisis mikrobiologi disterilkan dengan menggunakan autoklaf pada tekanan 15 psi pada suhu $121^{\circ} \mathrm{C}$ selama 15 menit.

2. Disiapkan larutan $\mathrm{NaCl}$ 0,9\% lalu dimasukkan ke dalam Erlenmeyer sebanyak $225 \mathrm{ml} 10^{-1}$. Masukkan larutan $\mathrm{NaCl}$ sebanyak $9 \mathrm{ml}$ ke dalam tabung reaksi yang sudah diberi tanda $10^{-2}$ dan $10^{-3}$, kemudian disterilkan dalam autoklaf pada suhu $121^{\circ} \mathrm{C}$ pada tekanan 15 psi selama 1 menit.

3. Disiapkan Nutrient Agar (NA) dengan cara ditimbang sebanyak 27,44 gram, dimasukkan ke dalam Erlenmeyer kemudian diberi Akuades sebanyak $980 \mathrm{ml}$. Selanjutnya homogenkan dengan menggunakan magnetic stirrer kemudian di-boil selama 20 menit pada air mendidih dan sterilkan di dalam autoklaf pada tekanan 15 psi dengan suhu $121^{\circ} \mathrm{C}$ selama 15 menit.

4. Sampel ditimbang sebanyak 25 gram secara aseptis kemudian dimasukkan ke dalam larutan $\mathrm{NaCl} 0,9 \%$ steril yang berisi $225 \mathrm{ml}$ larutan $\mathrm{NaCl}$ sehingga diperoleh larutan dengan pengenceran $10^{-1}$, dipipet $1 \mathrm{ml}$ ke dalam tabung reaksi kedua dengan pengenceran $10^{-2}$ kemudian homogenkan. Selanjutnya ganti pipet kemudian pipet sebanyak $1 \mathrm{ml}$ larutan dalam pengenceran $10^{-2}$ kemudian masukkan ke dalam tabung reaksi ketiga dengan pengenceran $10^{-3}$, kemudian homogenkan. Lakukan seterusnya tergantung berapa kali pengenceran yang akan dilakukan.

5. dari setiap pengenceran diambil masing-masing $1 \mathrm{ml}$ dan dimasukkan ke dalam 2 seri cawan petri steril yang telah diberi kode menurut jenis sampel dan tingkat pengencerannya.

6. Tuangkan $20 \mathrm{ml}$ Nutrient Agar (NA) ke masing-masing cawan petri. Setelah penuangan, cawan petri digoyang-goyang perlahan ke arah kiri, kanan, maju dan mundur dan biarkan media mengeras.

7. Masukkan cawan petri ke dalam inkubator yang bersuhu $37^{\circ} \mathrm{C}$ selama $24-48$ jam dalam posisi terbalik.

8. Setelah masa inkubasi berakhir, jumlah koloni bakteri yang dihitung pada cawan petri yaitu berjumlah 30-300 koloni. Dari jumlah tersebut dikalikan dengan pengencerannya.

$$
\text { Total Bakteri }=\frac{\text { Jumlah koloni } X 1}{\text { Faktor Pengenceran Per Cawan }}
$$




\section{Prosedur Uji Pigmen Total Kulit Buah Manggis.}

1. Manggis sebelum dibuat ekstrak disortir terlebih dahulu, manggis yang masih terlihat segar diambil untuk dibuat larutan.

2. Setelah mendapatkan manggis yang baik langkah selanjutnya adalah pencucian buah manggis. Setelah buah manggis bersih belah buah manggis tersebut satu-persatu dan kemudian pisahkan isinya.

3. Kulit manggis yang sudah dipisahkan dari isinya kemudian dipotong halus-halus dengan menggunakan gunting.

4. Keringkan kulit buah manggis selama 4 dan 8 hari pada sinar matahari.

5. Kulit manggis yang sudah kering kemudian dihaluskan dengan menggunakan blender dan dipisahkan untuk 4 dan 8 hari. Kemudian kulit buah manggis yang sudah berbentuk bubuk disimpan dengan menggunakan kantong plastik Ziplock.

6. Timbang bubuk kulit manggis sebanyak $50 \mathrm{~g}$ dan larutkan menggunakan etanol $95 \%$ sebanyak $200 \mathrm{ml}$ dalam tabung erlenmeyer $500 \mathrm{ml}$.

7. Bubuk diekstraksi selama 24 jam dan disaring menggunakan kain blacu.

8. Hasil saringan diambil $5 \mathrm{ml}$ untuk dianalisa pigmen total.

9. Ekstrak pigmen total dianalisis dengan serapan spektrofotometer UV-Vis 1800 Shimadzu diantara panjang gelombang 380-550 $\mathrm{nm}$. Serapan tersebut membentuk puncak serapan spektrofotometer sehingga dapat diidentifikasi serta dapat menentukan nilai kuantitas dan kandungan konsentrasi pada ekstrak pigmen total dengan menggunakan metode matematis merujuk pada Briton, et al., (1995).

$$
\mathrm{C}=\frac{\mathrm{OD} \times \mathrm{V}}{\mathrm{E}_{1}^{1 \%} \mathrm{~cm} \cdot \mathrm{P}} \text { dan } \mathrm{C}=\frac{\mathrm{OD} \times \mathrm{V}}{\mathrm{E}_{1 \mathrm{~cm}}^{1 \%}}
$$

Ket.: $\mathrm{Q}=$ Kandungan Pigmen $(\mu \mathrm{g}) ; \mathrm{C}=$ Konsentrasi Pigmen $(\mu \mathrm{g} / \mathrm{g}$ berat residu kering); OD = Kepadatan Optik/Optical density (pengukuran dengan spektrometer); V = Volume Pigmen $(\mathrm{ml}) ; \mathrm{E}_{1 \mathrm{~cm}}^{1 \%}=$ Extinction Coefficiant $(0,2) ; \mathrm{P}=$ Berat Residu Kering (g).

\section{Uji Kandungan Antosianin total dalam kulit buah manggis}

Kulit buah manggis yang telah diblender halus dilarutkan dengan etamol 95\%. Lalu larutan tersebut diukur serapannya menggunakan spektrofotometer UV-Vis pada panjang gelombang 520 $\mathrm{nm}$ dan $700 \mathrm{~nm}$. Kandungan antosianin total dalam kulit buah manggis dihitung menggunakan perhitungan dengan koefisien ekstingsi molar $(\varepsilon)$ sebesar 29.600 (berdasarkan koefisien ekstingsi molar dari sianidin-3 glukosida) dan bobot molekul sebesar 449,2 sebagai berikut:

$$
\text { Total antosianin }(\mathrm{mg} / \mathrm{L}): \frac{A \times M W \times D F \times 10^{3}}{\varepsilon \times 1}
$$

Ket.: A: $(A 520 \mathrm{~nm}-\mathrm{A} 700 \mathrm{~nm})-(\mathrm{A} 520 \mathrm{~nm}-\mathrm{A} 700 \mathrm{~nm})$; E: koefisien ekstingsi molar $\left(\mathrm{L} \mathrm{x} \mathrm{mol}^{-1} \mathrm{x} \mathrm{cm}^{-1}\right)$; MW: Bobot molekul; DF: Faktor pengenceran; 1: Tebal kuvet $(1 \mathrm{~cm})($ Lee, et al., 2005).

\section{HASIL DAN PEMBAHASAN}

\section{Analisa Pigmen Total Kulit Buah Manggis}

Ekstrak pigmen total dari kulit buah manggis. diambil $5 \mathrm{ml}$ ekstrak dari masing-masing sampel, selanjutnya diserap dengan menggunakan spektrofotometer UV-Vis pada panjang gelombang 400-700 $\mathrm{nm}$. Hasil analisis serapan maksimum spektrofotometer pada ekstrak kulit buah manggis dapat dilihat Gambar 1. 


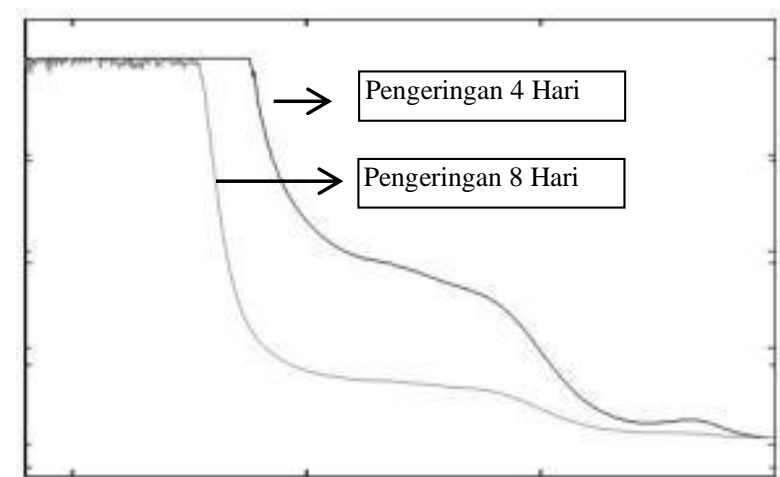

Gambar 1. Hasil analisis serapan maksimum spektrofotometer pada ekstrak kulit buah manggis.

Scanning menggunakan spektrofotometer UV-Vis terlihat bahwa gambar di atas memiliki peak area pada gelombang 400-700 nm. Antosinin adalah pigmen warna yang memiliki serapan di daerah visible dengan panjang gelombang 505-535 nm (Supiyanti et al., 2010). Jika dilihat pada Gambar 1 dari hasil scanning menunjukkan kemungkinan adanya pigmen antosianin. Menurut Hidayat\& Saati (2006), dalam tanaman ada berbagai macam pigmen zat warna antara lain karoten, biksin, karamel, klorofil, tanin dan antosianin.

Menurut Monica et al., (2013), Gugus kromofor dan tipe gula yang terikat pada antosianin menyebabkan absorbsi cahaya pada antosianin berbeda dari spektrum UV-Vis. Adanya ikatan rangkap terkonjugasi pada gugus kromofor yang terdapat dalam struktur antosianin membuat antosianin dapat menyerap cahaya pada daerah sinar tampak, sehingga memungkinkan analisis pigmen tersebut secara spektroskopi. Makin banyak dan panjang susunan ikatan rangkap terkonjugasi pada struktur antosianin, warna yang dihasilkan pada tanaman akan semakin kuat dan mengakibatkan penyerapan cahaya UV-Vis terjadi pada panjang gelombang yang lebih panjang. Hal ini disebabkan energi yang diperlukan untuk mengalami transisi pada ikatan rangkap terkonjugasi makin kecil, sehingga absorbsi akan semakin bergeser ke panjang gelombang yang lebih besar.

\section{Pigmen Total Kulit Buah Manggis}

Tabel 1. Konsentrasi pigmen total dari perhitungan dengan menggunakan esktrak kulit buah manggis.

\begin{tabular}{cccccc}
\hline No. & $\begin{array}{c}\text { Pigmen Total waktu } \\
\text { pengeringan 4 Hari }(\boldsymbol{\mu g} / \mathbf{g})\end{array}$ & $\begin{array}{c}\text { Pigmen Total waktu } \\
\text { pengeringan 8 Hari }(\boldsymbol{\mu g} / \mathbf{g})\end{array}$ & $\begin{array}{c}\text { No. } \\
\text { Pigmen Total waktu }\end{array}$ & $\begin{array}{c}\text { Pigmen Total waktu } \\
\text { pengeringan 4 Hari }(\boldsymbol{\mu g} / \mathbf{g})\end{array}$ \\
$\mathbf{p e n g e r i n g a n} 8 \mathrm{Hari}(\boldsymbol{\mu} \mathbf{g}) \mathbf{g})$
\end{tabular}

Dapat dilihat pada tabel 1 bahwa terdapat perbedaan nilai kandungan pigmen total antara perlakuan lama pengeringan antara 4 dan 8 hari. Nilai yang diperoleh dari perlakuan pengeringan 8 hari lebih rendah dibandingkan dengan perlakuan pengeringan 4 hari. Hal ini menunjukkan bahwa semakin lama perlakuan akan semakin menurunkan nilai kandungan pigmen total. Lamanya perlakuan pengeringan bisa mempengaruhi terjadinya degradasi pada antosianin. Kondisi bebas 
cahaya, temperatur rendah, kopigment, ion logam, oksigen, enzim, konsentrasi dan tekanan pun menjadi faktor penting agar kestabilan antosianin tetap terjaga sehingga kesetimbangan antosianin tidak mudah bergeser dan pada akhirnya mengalami degradasi (Marszalek et al., 2017).

\section{Kadar Antosianin Esktrak Kulit Buah Manggis}

Hasil perhitungan kadar antosianin dengan metode lee, et al., (2005).

Tabel 2. Hasil perhitungan kadar antosianin.

\begin{tabular}{|c|c|c|c|c|c|}
\hline No. & $\begin{array}{c}\text { Antosianin waktu } \\
\text { pengeringan } 4 \text { Hari }(\mathrm{Mg} / \mathrm{L})\end{array}$ & $\begin{array}{c}\text { Antosianin waktu } \\
\text { pengeringan } 8 \text { Hari }(\mathrm{Mg} / \mathrm{L})\end{array}$ & No. & $\begin{array}{c}\text { Antosianin waktu } \\
\text { pengeringan } 4 \text { Hari }(\mathrm{Mg} / \mathrm{L})\end{array}$ & $\begin{array}{c}\text { Antosianin waktu } \\
\text { pengeringan } 8 \text { Hari }(\mathrm{Mg} / \mathrm{L})\end{array}$ \\
\hline 1 & 191,11 & 62,37 & 17 & 172,83 & 57,19 \\
\hline 2 & 189,44 & 61,86 & 18 & 172,24 & 57,02 \\
\hline 3 & 187,94 & 61,45 & 19 & 171,58 & 56,85 \\
\hline 4 & 186,44 & 60,95 & 20 & 171,08 & 56,69 \\
\hline 5 & 185,02 & 60,53 & 21 & 170,57 & 56,52 \\
\hline 6 & 183,60 & 60,19 & 22 & 170,16 & 56,44 \\
\hline 7 & 182,26 & 59,78 & 23 & 169,91 & 56,35 \\
\hline 8 & 181,09 & 59,44 & 24 & 169,41 & 56,19 \\
\hline 9 & 179,84 & 59,11 & 25 & 169,15 & 56,10 \\
\hline 10 & 178,84 & 58,78 & 26 & 168,74 & 56,02 \\
\hline 11 & 177,84 & 58,52 & 27 & 168,49 & 55,94 \\
\hline 12 & 176,67 & 58,27 & 28 & 168,15 & 55,85 \\
\hline 13 & 175,75 & 58,02 & 29 & 167,82 & 55,77 \\
\hline 14 & 175,00 & 57,77 & 30 & 167,57 & 55,69 \\
\hline 15 & 174,16 & 57,52 & 31 & 167,23 & 55,52 \\
\hline 16 & 173,50 & 57,36 & & & \\
\hline
\end{tabular}

Dari hasil perhitungan yang diperoleh kadar pigmen antosianin 4 dan 8 hari memiliki kadar yang berbeda. Kadar antosianin 8 hari lebih rendah dibandingkan dengan kadar antosianin 4 hari. Kadar tersebut dipengaruhi oleh perlakuan pengeringan. Sehingga, kadar antosianin yang lebih baik diperoleh dari perlakuan pengeringan 4 hari untuk mendapatkan kadar antosianin yang lebih baik.

Dapat diamati dari tabel 1 dan 2 bahwa lama perlakuan pengeringan mempengaruhi kadar pigmen dalam ekstrak etanol kulit buah manggis. Semakin lama perlakuan maka kadar pigmen yang diperoleh semakin rendah.

\section{Analisa Nilai Angka Lempeng Total (ALT)}

Dari hasil penelitian menjelaskan bahwa pengaruh lama penyimpanan ikan cakalang asap yang diberi larutan kulit buah manggis disimpan pada suhu ruang $\left(28-30^{\circ} \mathrm{C}\right)$ jumlah koloni semakin lama semakin meningkat dapat dilihat pada Gambar 2.

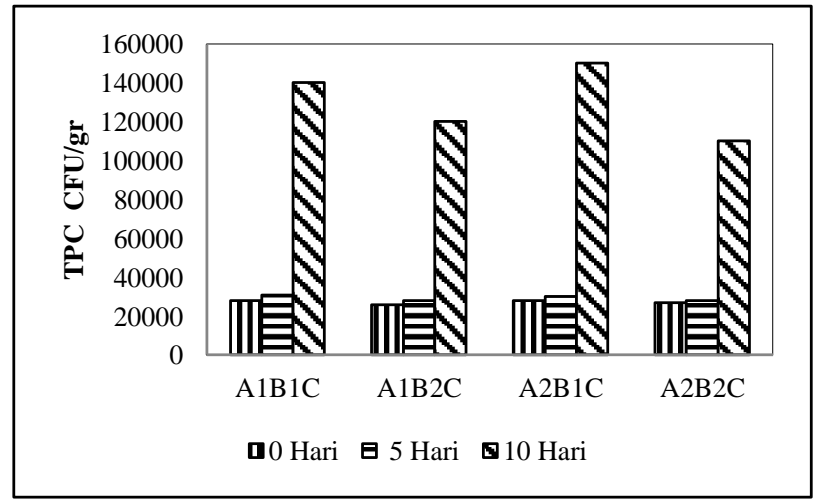

Gambar 2. Histogram total plate count ikan cakalang asap yang direndam esktrak kulit buah manggis dengan perlakuan pengeringan 4 dan 8 hari.

Ket.: A1B1C $=$ Pengeringan 4 hari lama perendaman 15 menit ; A1B2C $=$ Pengeringan 4 hari lama perendaman 30 menit; $\mathrm{A} 2 \mathrm{~B} 1 \mathrm{C}=$ Pengeringan 8 hari lama perendaman 15 menit; A2B2C = Pengeringan 8 hari lama perendaman 30 menit; $\mathrm{C}=$ Lama penyimpanan 0,5 dan 10 hari. 
Berdasarkan gambar tersebut dapat dilihat pengaruh pada ikan cakalang asap yang direndam dengan ekstrak kulit manggis dan disimpan selama penyimpanan suhu ruang mengalami penurunan kualitas mutu. Meningkatnya jumlah bakteri disebabkan karena mutu produk ikan asap mengalami penurunan mutu akibat penyimpanan pada suhu ruang. Menurut Berhimpon (1995) bahwa meningkatnya jumlah koloni bakteri berhubungan dengan meningkatnya nilai $\mathrm{pH}$ produk selama penyimpanan dan juga temperatur ruang penyimpanan produk $\left(25-30^{\circ} \mathrm{C}\right)$. llyas (1983), Pertumbuhan bakteri pada ikan sangat dipengaruhi oleh suhu, semakin rendahnya suhu ikan semakin lambat pertumbuhan bakteri. Selama penyimpanan akan terjadi perubahan dekomposisi baik oleh flora bakteri maupun oleh enzim proteolitik. Ketersedian oksigen juga membatasi pertumbuhan mikroba akan terhambat. Fardiaz (1989), Mengungkapkan bahwa faktor - faktor yang mempengaruhi pertumbuhan mikroorganisme antara lain meliputi intrinsik dan eksterinsik, proses, dan implisit. Faktor intrinsik meliputi PH, aktivitas air (aw), kemampuan mengoksidasi-reduksi, kandungan nutrient, bahan antimikroba dan struktur makanan. Faktor ekstrinsik yang mempengaruhi pertumbuhan mikroorganisme adalah suhu penyimpanan, kelembaban, tekanan gas $\left(\mathrm{O}^{2}\right)$, cahaya dan pengaruh sinar ultraviolet.

Pada penyimpanan 10 hari terjadi peningkatan nilai koloni bakteri, hal ini disebabkan bakteri dan kapang mulai bertumbuh dan berkembang biak. Hal ini dipertegas oleh Buckle et al. (1985), bahwa pada tahap awal pertumbuhan mikroorganisme belum terjadi pembelahan sel. Selanjutnya setelah mampu beradaptasi dengan lingkungannya yang baru, sel-sel bakteri akan tumbuh dan membelah secara eksponsil sampai jumlah yang maksimum. Pada histogram di atas menjelaskan kombinasi perlakuan A1B1C dari 0 hari sampai hari ke 10 nilai koloni mengalami peningkatan. nilai rata-rata pada 0 hari adalah 2,8 koloni/gram. kemudian, pada hari ke 5 nilai koloni mengalami peningkatan dengan nilai rata-rata 3,1 koloni/gram kemudian pada hari ke 10 nilai rata-rata koloni adalah 1,40 koloni/gram. Pada kombinasi perlakuan A1B2C nilai rata-rata dari 0 hari sampai hari ke 10 nilai koloni mengalami peningkatan. Pada 0 hari nilai rata-rata adalah 2,6 koloni/gram kemudian, pada hari ke 5 mengalami peningkatan dengan nilai 2,8 koloni/gram. Kemudian pada hari ke 10 nilai koloni juga mengalami peningkatan dengan nilai rata-rata 1,20 koloni/gram. Pada kombinasi perlakuan A2B1C dari 0 hari sampai hari ke 10 jumlah bakteri mengalami peningkatan. pada 0 hari nilai rata- rata adalah 2,8 koloni/gram kemudian, pada hari ke 5 nilai rata-rata koloni 3,0 koloni/gram kemudian, pada hari ke 10 nilai bakteri juga mengalami peningkatan dengan nilai rata- rata 1,50 koloni/gram. Pada kombinasi perlakuan A2B2C dari 0 hari sampai hari ke 10 nilai pertumbuhan bakteri mengalami peningkatan. nilai rata-rata pada 0 hari adalah 2,7 koloni/gram kemudian nilai rata-rata hari ke 5 adalah 2,8 koloni/gram, begitu pula pada hari ke 10 nilai rata-rata pertumbuhan koloni meningkat yaitu 1,10 koloni/gram.

Hasil penelitian menunjukkan bahwa larutan kulit buah manggis dapat menekan jumlah pertumbuhan bakteri karena jumlah bakteri dari 0 hari sampai hari ke 10 masih di bawah Standarisasi Nasional Indonesia (SNI). Berdasarkan persyaratan mutu yang dikeluarkan oleh Badan Standarisasi Nasional Indonesia (SNI 01-2725-1992) jumlah bakteri maksimum untuk ikan asap adalah $5 \times 10^{5} \mathrm{koloni} / \mathrm{gram}$. Hal ini berarti bahwa produk ikan cakalang asap yang diberi larutan kulit buah manggis yang mengalami penyimpanan dari 0 hari sampai hari ke 10 masih layak untuk dikonsumsi karena jumlah bakteri pada hari ke 10 lebih rendah dibandingkan dengan Standarisasi Nasional Indonesia (SNI). Nilai pertumbuhan bakteri ikan cakalang asap yang diberi larutan kulit buah manggis pada hari ke 10 adalah $1,50 \times 10^{5} \mathrm{koloni} / \mathrm{gram}$.

\section{KESIMPULAN}

Dari hasil analisis pigmen total pada lama pengeringan 4 dan 8 hari memperoleh nilai berbeda. Nilai tertinggi terdapat pada lama pengeringan 4 hari yaitu $68,67 \mu \mathrm{g} / \mathrm{g}$ dan nilai terendah terdapat pada lama pengeringan 8 hari yaitu 19,95 $\mu \mathrm{g} / \mathrm{g}$. Dari hasil analisis kadar antosianin lama pengeringan 4 dan 8 hari diketahui memperoleh kadar antosianin yang berbeda. Kadar antosianin lama pengeringan 4 hari yaitu 191,11 mg/L. Dan kadar antosianin 8 hari memiliki kadar 62,37 $\mathrm{mg} / \mathrm{L}$. Dari hasil analisis nilai Total Plate Count larutan ekstrak kulit buah manggis dapat menekan jumlah pertumbuhan bakteri karena jumlah bakteri dari penyimpanan 0, 5 dan 10 hari masih memenuhi syarat SNI. Nilai Angka Lempeng Total (ALT) tertinggi terdapat pada konsentrasi $50 \mathrm{~g}$ pengeringan 8 hari lama perendaman 15 menit dengan nilai 1,50 koloni/gram. Sedangkan nilai 
ALT terendah terdapat pada konsentrasi $50 \mathrm{~g}$ pengeringan 4 hari lama perendaman 30 menit dengan nilai 2,6 koloni/gram. Perlu dilakukan penelitian lebih lanjut untuk mengetahui pengeringan yang efektif terhadap kulit buah manggis agar memperoleh pigmen total dan kadar antosianin yang banyak.

\section{DAFTAR PUSTAKA}

Badan Pusat Statistik, (2017). Data Produksi Buah Manggis. BPS. Jakarta Pusat.

Badan Standardisasi Nasional Republik Indonesia. (1992).SNI 01-2725-1992. Tentang Mutu Ikan Asap.

Bentalen, S. G., Onibala, H., \& Salindeho, N. (2017). Mutu Ikan Cakalang (Katsuwonus Pelamis L) Asap Yang Direndam Dengan Larutan Kulit Buah Manggis (Gracinia Mangostana Linn). Media Teknologi Hasil Perikanan, 5(1), 13-18.

Berhimpon, S. (1995). Studi Pengemasan dan Penyimpanan ikan asap dan produk Olahannya. Penelitian Mandiri. Fakultas Perikanan dan Ilmu Kelautan. Universitas Sam Ratulangi. Sulawesi Utara. Manado.

Britton, G. (1995). UV/Visible spectroscopy In Carotenoids, Volume 1B: Spectroscopy (Britton G., editor;, Liaaen-Jensen S., editor; and Pfander H., editor. Eds.).

Buckle, K. A., Edwards, R. A., Fleet, G. H., \& Wotton, M. (1987). Ilmu Pangan. Penerjemah Hari Purnomo dan Adiono. Universitas Indonesia Prees. Jakarta.

Fardiaz, S. (1989). Mikrobiologi Pangan. Pusat Antar Universitas Pangan dan Gizi.

Fardiaz, S. (1993). Analisis Mikrobiologi Pangan Edisi Pertama. Cetakan Pertama. Raja Grafindo Persada, Jakarta.

Hidayat, N., \& Saati, E. A. (2006). Membuat Pewarna Alami. Cetakan I. Surabaya (ID): Trubus Agrisarana, 52.

IIyas, S, (1983). Teknologi Refrigrasi Hasil Perikanan. Jilid 1. Teknik Pendinginan Ikan. C. V. Paripurna, Jakarta.

Lee, J., Durst, R. W., \& Wrolstad, R. E. (2005). Determination of total monomeric anthocyanin pigment content of fruit juices, beverages, natural colorants, and wines by the $\mathrm{pH}$ differential method: collaborative study. Journal of AOAC international, 88(5), 1269-1278.

Marszałek, K., Woźniak, Ł., Kruszewski, B., \& Skąpska, S. (2017). The effect of high pressure techniques on the stability of anthocyanins in fruit and vegetables. International journal of molecular sciences, 18(2), 277.

Monica, S. H., Avriliana, D. A., \& Andri Cahyo, K. (2013). Penentuan Jenis Solven dan pH Optimum pada Analisis Senyawa Delphinidin dalam Kelopak Bunga Rosela dengan Metode Spektrofotometri UV-Vis. Jurnal Teknologi Kimia dan Industri, 2(2), 91-96.

Muslichah, S., Anggraini, D., \& Waluyo, J. (2013). Uji Aktivitas Antibakteri Ekstrak Etil Asetat Kulit Buah Manggis (Garcinia mangostana L.) Terhadap Streptococcus mutans.

Republik Indonesia (1996). Undang-Undang No. 7 Tahun 1996 Tentang Pangan. Lembaran Negara RI Tahun 1996, No. 99. Sekretariat Negara. Jakarta.

Republik Indonesia (2004). Undang-Undang No. 31 Tahun 2004 Tentang Perikanan. Lembaran Negara RI Tahun 2004, No. 4433. Sekretariat Negara. Jakarta.

Steel, G. D., h Torrie, J., \& Sumantri, B. (1991). Prinsip dan prosedur statistika: suatu pendekatan biometrik. Gramedia Pustaka Utama.

Subroto, I. M. A. (2008). Real food true health. AgroMedia.

Swastawati, F; Boesono, Herry; Wijayanto, Dian. (2013a). Pengasapan Ikan Bandeng Tanpa Duri Menggunakan Asap Cair. Unikal Press, Universitas Pekalongan. Pekalongan. $102 \mathrm{hlm}$.

Swastawati, F. (2008). Pemanfaatan Berbagai Limbah Pertanian sebagai Bahan Baku Asap Cair dan Penerapan Asap Cair Terbaik pada Ikan Manyung, Tongkol, Pari serta Riset Pemasaran, Strategi Pemasaran, dan Studi Kelayakannya.[Disertasi]. Program Pasca Sarjana Manajemen Sumber Daya Perairan. Universitas Diponegoro. Semarang, $345 .$.

Tambunan, R. M. (1998). Telaah Kadungan Kimia dan Aktivitas Antimikroba Kulit Buah Manggis (Doctoral dissertation, Tesis. Institut Teknologi Bandung, Bandung).

Verheij, E. W. M. (1997). Garcinia mangostana L, p. 220-225. In E. W. M. Verheijdan R. E. Coronel (Eds). Edible Fruits and Nuts. Plant Recources of South East Asia. Bogor.

Widia, S., (2013). Daya Hambat Ekstrak Kulit Manggis Terhadap Pertumbuhan Polibakteri Recurrent Aphthous Stomattis. [Skripsi] Universitas Airlangga. Surabaya.

Yu, L., Zhao, M., Yang, B., Zhao, Q., \& Jiang, Y. (2007). Phenolics from hull of Garcinia mangostana fruit and their antioxidant activities. Food chemistry, 104(1), 176-181.

Zadernowski, R., Czaplicki, S., \& Naczk, M. (2009). Phenolic acid profiles of mangosteen fruits (Garcinia mangostana). Food Chemistry, 112(3), 685-689. 